\title{
Skeletal Muscle Metabolic Dysfunction in Obesity and Metabolic Syndrome
}

\author{
Greg D. Wells, Michael D. Noseworthy, Jill Hamilton, \\ Mark Tarnopolski, Ingrid Tein
}

\begin{abstract}
Obesity and the related metabolic syndrome have become a worldwide epidemic. Inactivity appears to be a primary causative factor in the pathogenesis of this obesity and metabolic syndrome. There are two possible, perhaps not mutually exclusive, events that may lead to intramyocellular lipid accumulation and mitochondrial dysfunction in patients with obesity. First, obesity, with high intake-associated lipid accumulation in muscle may interfere with cellular mitochondrial function through generation of reactive oxygen species leading to lipid membrane peroxidative injury and disruption of mitochondrial membrane-dependent enzymes. This in turn leads to impaired oxidative metabolism. Secondly, a primary defect in mitochondrial oxidative metabolism may be responsible for a reduction in fatty acid oxidation leading to intramyocellular lipid accumulation as a secondary event. Non-invasive techniques such as proton $\left({ }^{1} \mathrm{H}\right)$ and phosphorus $\left({ }^{31} \mathrm{P}\right)$ magnetic resonance spectroscopy, coupled with specific magnetic resonance imaging techniques, may facilitate the investigation of the effects of various ergometric interventions on the pathophysiology of obesity and the metabolic syndrome. Exercise has positive effects on glucose metabolism, aerobic metabolism, mitochondrial density, and respiratory chain proteins in patients with metabolic syndrome, and we propose that this may be due to the exercise effects on AMP kinase, and a prospective physiological mechanism for this benefit is presented. A physiological model of the effect of intramyocellular lipid accumulation on oxidative metabolism and insulin mediated glucose uptake is proposed.
\end{abstract}

RÉSUMÉ: Dysfonction métabolique des muscles squelettiques dans l'obésité et le syndrome métabolique. L'obésité et le syndrome métabolique, deux entités qui sont reliées, sont devenus épidémiques à l'échelle mondiale. L'inactivité semble être le facteur causal primaire. Il existe deux possibilités, qui ne sont peut-être pas mutuellement exclusives, qui peuvent conduire à une accumulation intramyocellulaire de lipides et à une dysfonction mitochondriale chez les patients obèses. D'une part l'obésité, avec une accumulation musculaire de lipides suite à une consommation élevée de lipides, peut interférer avec la fonction mitochondriale à cause de la production de radicaux libres qui provoquent la peroxydation des lipides membranaires et la perturbation des enzymes mitochondriales dépendantes de la membrane entravant ainsi le métabolisme oxydatif. D’autre part, un défaut primaire dans le métabolisme oxydatif mitochondrial pourrait être responsable d'une diminution de l'oxydation des acides gras, ce qui entraînerait secondairement une accumulation lipidique intramyocellulaire. Des techniques non-effractives comme la spectroscopie RMN du proton $(1 \mathrm{H})$ et du phosphore (31P), couplées à des techniques spécifiques d'imagerie par résonance magnétique pourraient faciliter l'étude des effets de différentes interventions ergométriques sur la physiopathologie de l'obésité et du syndrome métabolique. L'exercice a des effets positifs sur le métabolisme du glucose, le métabolisme aérobique, la densité mitochondriale et les protéines de la chaîne respiratoire chez les patients atteints du syndrome métabolique, ce qui porte à croire que l'exercice influence la kinase activée par l'AMP et nous proposons un mécanisme physiologique pour l'expliquer. Nous présentons également un modèle physiologique de l'effet de l'accumulation lipidique intramyocellulaire sur le métabolisme oxydatif et sur la captation du glucose médiée par l'insuline.

Can. J. Neurol. Sci. 2008; 35: 31-40

\section{The Rising 'Epidemic' of Childhood Obesity and its Impact on Population Health}

Obesity is a worldwide 'epidemic' with $34 \%$ of Canadians 20 years and older classified as overweight and $16 \%$ classified as obese in 2003. ${ }^{1}$ The Canadian Paediatric Society defines children as overweight when the body mass index (BMI) exceeds $85 \%$ of age-specific growth charts for ages 2 to 19 years, and obesity is defined as a BMI $>95 \%$. $^{2}$ In Canada, BMI has increased nearly $0.1 \mathrm{~kg} / \mathrm{m}^{2}$ per year since 1981 for both genders at most ages. ${ }^{3}$ The prevalence of overweight/obesity among children aged 2 17 years was $26 \%$ in 2004 , which represents a doubling of overweight and tripling of obesity over the past 25 years. ${ }^{4}$ The prevention of obesity in children and youth has become a national public health priority. ${ }^{5}$

\footnotetext{
From the Department of Pediatrics, Department of Laboratory Medicine and Pathobiology (IT), Division of Endocrinology (JH), Physiology and Experimental Medicine, Department of Anesthesia (GDW), The Hospital for Sick Children, Toronto General Hospital, University of Toronto, Toronto; Departments of Electrical \& Computer Engineering, Medical Physics, and Biomedical Engineering, Brain-Body Institute, McMaster University (MDN); Neuromuscular and Neurometabolic Clinic (MT), McMaster University Medical Center, Hamilton, Ontario, Canada. Received May 31, 2007. Final Revisions Submitted OCtober 17, 2007. Reprint requests to: Greg D. Wells, Division of Respiratory Medicine, Rm 4534, The Hospital for Sick Children, 555 University Ave., Toronto, Ontario, M5G 1X8, Canada.
} 
Associated morbidity includes the metabolic syndrome (MS) (dyslipidemia, hypertension, insulin resistance, type 2 diabetes mellitus and non-alcoholic steatohepatitis), which is also known as insulin resistance syndrome. Early childhood and adolescent periods appear to be critical in the development of obesity and MS but the mechanisms in this development are not clear. ${ }^{6}$ According to the US 2002 National Cholesterol Education Program Expert Panel, the diagnosis of metabolic syndrome in adolescents requires the presence of at least three of the following 1) abdominal obesity 2) hypertriglyceridemia 3) abnormal cholesterol profile and high-density lipoproteins 4) blood pressure $>90$ percentile, and 5) impaired glucose tolerance. Some possible causes may include poor nutrition and diet, lack of physical activity, socioeconomic factors, prenatal/early life parental habits, and genetic and endocrine factors. ${ }^{7}$ Numerous genetic markers are linked with obesity, yet identifiable hormonal, syndromic or molecular genetic abnormalities presently account for $<5 \%$ of obesity. ${ }^{8}$

Weiss et $\mathrm{al}^{9}$ found that the risk of metabolic syndrome was nearly $50 \%$ in severely obese children. Causal links between obesity in the young and earlier-onset of type 2 diabetes are significantly correlated..$^{10}$ Type 2 diabetes in youth is responsible for $20 \%$ of new diabetic cases in pubertal children. ${ }^{11}$ Visceral adipose tissue is associated with the greatest health risk in obesity. ${ }^{12}$ In obese children and adolescents with pre-diabetes, intramyocellular lipid and intra-abdominal lipid accumulation is closely linked to the development of severe peripheral insulin resistance. ${ }^{13}$ Further, it is becoming evident that obesity and insulin resistance may be linked to the dysregulation of fatty acid oxidation. ${ }^{14}$

The evidence that obesity and metabolic syndrome may be linked to activity levels, as well as evidence of the associated intramyocellular lipids and fatty acid oxidation dysregulation in skeletal muscle suggest that muscle may play a significant role in the pathogenesis of these conditions. Therefore, the objective of this paper is to present a detailed review of the pathophysiology of childhood obesity with special attention to skeletal muscles as muscle plays a key role in whole body lipid metabolism and in the increase of intramyocellular lipid (IMCL) seen in obesity. Further, we suggest non-invasive techniques that can be used to accurately evaluate muscle metabolism and a physiological rationale for the use of exercise as a treatment modality for this population.

\section{The Role of Skeletal Muscle Fatty Acid Oxidation and Intramyocellular Lipid Accumulation in the Development of Metabolic Syndrome in Obesity}

Skeletal muscle plays an essential role in fatty acid oxidation. At rest, up to $90 \%$ of muscle energy requirements are obtained from fatty acid oxidation. ${ }^{14}$ Thus skeletal muscle, by virtue of its mass, is quantitatively a key factor in deciding the fate of circulating lipid. An increase in muscle lipid may be associated with a reduction in muscle lipid oxidation, thus promoting lipid accretion, ${ }^{15}$ observable as an increase in intramyocellular lipid and triglycerides (see Figure 1). ${ }^{16,17}$ The increase in intramyocellular lipid observed in obesity may impair fatty acid oxidation itself or be secondary to impaired fatty acid oxidation in muscle and is linked to insulin resistance and the metabolic syndrome in obesity. This relationship is important, as an increase in intramyocellular lipid has been linked, more tightly than BMI or total body fat, ${ }^{18}$ to insulin resistance in obesity. ${ }^{15,19}$ A reduced ability to oxidize fatty acids has been reported in skeletal muscle of obese individuals both before and after weight loss,${ }^{15,20}$ which would support an intrinsic abnormality of fatty acid oxidation as a potential underlying predisposing factor in obesity. Possible mechanisms of reduced oxidative capacity include activity of enzymes involved in fatty acid oxidation such as carnitine palmitoyltransferase-1 (CPT-1) activity and reduced citrate synthase activity. ${ }^{20}$ In obesity-related insulin resistance, the metabolic capacity of skeletal muscle appears to be organized toward fat esterification rather than oxidation. ${ }^{21}$ Postprandial uptake of ${ }^{13}$ Carbon-labeled fatty acids by muscle is also increased in obesity. ${ }^{22}$ This may contribute to the elevated intramyocellular lipids and consequent insulin resistance. Thus, there is evidence for dysregulation of fatty acid oxidation in obesity and related morbidities. A model describing the hypothetical pathogenesis of oxidative metabolism and altered glucose uptake that occurs with increases in intramyocellular lipids is described in Figure 1.
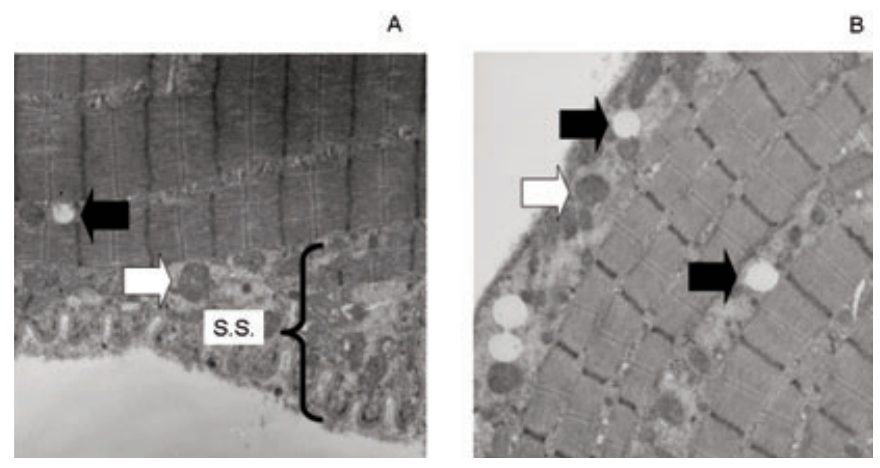

Figure 1: Electron microscopy images of a lean (A) and an obese (B) individual. Solid arrow =IMCL (note greater number in obese); open arrow $=$ mitochondria $;$ S.S. = sub-sarcolemmal region $($ magnification $=$ 7,500X). (from M. Tarnopolsky, unpublished results).

The key question as to whether skeletal muscle intramyocellular lipid accumulation is a marker or a mediator of obesity-induced insulin resistance in type 2 diabetes has been raised by Goodpaster \& Kelley. ${ }^{23}$ The inability of insulin to stimulate glucose metabolism in skeletal muscle in obesity is characteristic of type 2 diabetes and involves defects of insulin signaling and glucose transport ${ }^{24-27}$ (see Step 9, Figure 2). However, this insulin resistance entails altered patterns of lipid metabolism as well. The association between intramyocellular lipids and insulin resistance has been established in both human and animal studies of obesity-related insulin resistance and type 2 diabetes. The muscle's ability to select substrates for fuel metabolism and to transition between carbohydrates and fatty 

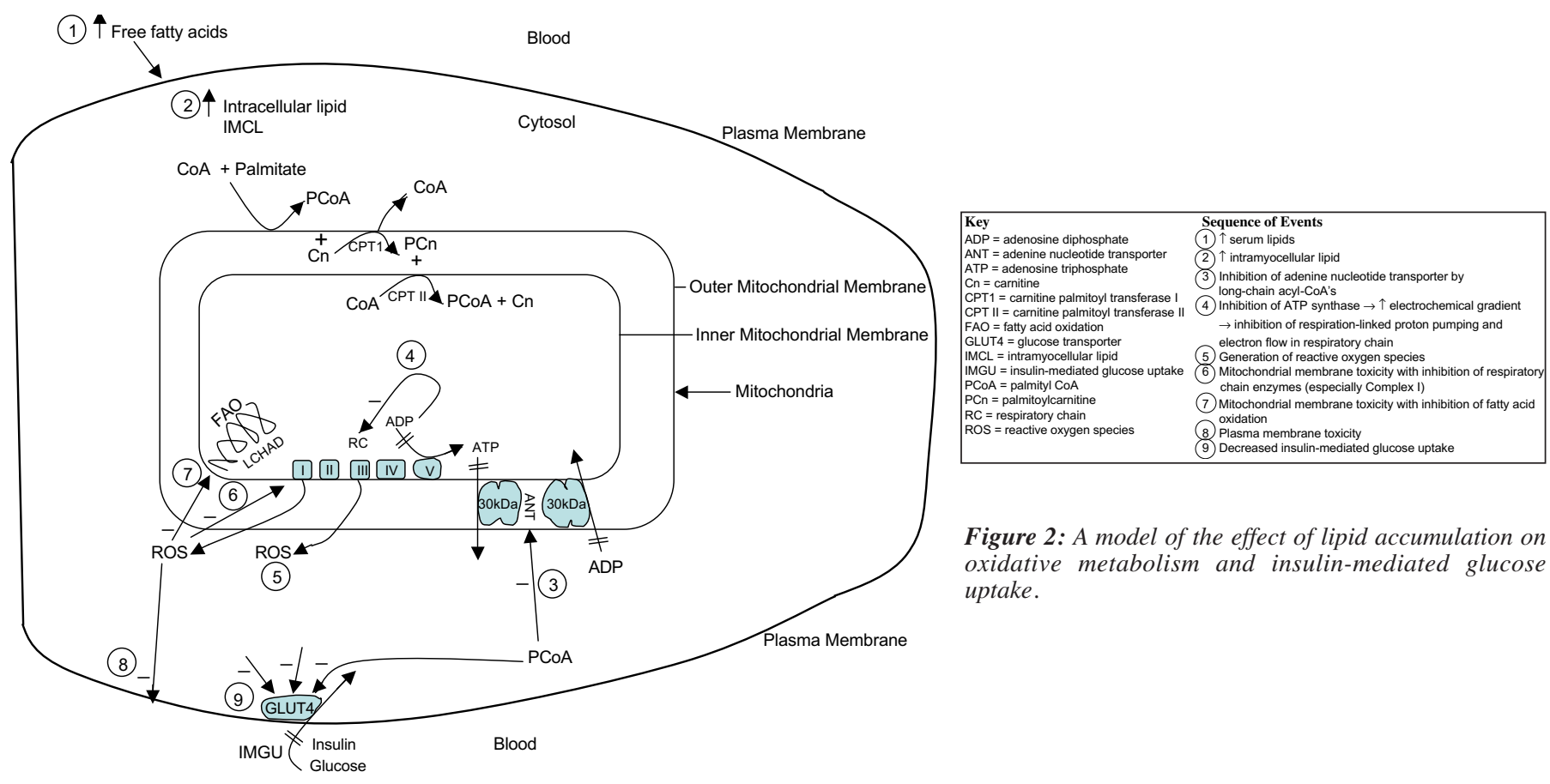

Figure 2: A model of the effect of lipid accumulation on oxidative metabolism and insulin-mediated glucose uptake.

acid oxidation is lost in insulin resistance. ${ }^{28}$ Defects in fatty acid oxidation during fasting or post-absorptive conditions likely play a key role in lipid oversupply to insulin resistance in muscle. These impairments appear indirectly centred on the mitochondrial ability to oxidize fatty acids, possibly through the mediation of lipid metabolites, which directly attenuate insulin signalling. ${ }^{23}$ There is now compelling evidence to suggest that abnormal fat accumulation in muscle and other tissues plays an important role in the etiology of insulin resistance. This is supported by the following findings: 1) artificial elevation of circulating free fatty acid levels can, over a few hours, result in a significant suppression of insulin-mediated glucose uptake into muscle in healthy individuals: ${ }^{29-31}$ 2) this effect correlates temporally with intramyocellular lipid accumulation in muscle; 3) diet-induced lowering of tissue intramyocellular lipid improves insulin sensitivity and reverses the diabetes in type 2 diabetes animal models. ${ }^{32,33}$ Thus, increased intramyocellular lipid may be instrumental in bringing about the decline in muscle insulin sensitivity. ${ }^{18}$ Research that defines these mechanisms may lead to treatments for obesity and type 2 diabetes. ${ }^{34}$

One hypothesis to account for the effects of fatty acids in muscle cells proposes that increasing intramyocellular fatty acid metabolites, such as diacylglycerol, fatty acyl Coenzyme As (CoA's), or ceramides, activates a serine / threonine kinase cascade leading to the phosphorylation of insulin receptor substrates (see Figure 3). ${ }^{18,24}$ Serine-phosphorylated forms of these proteins fail to activate phosphatidylinositol 3-kinase, resulting in decreased activation of glucose transport and other downstream events. If this hypothesis is correct, any perturbation that results in the accumulation of intracellular fatty acid
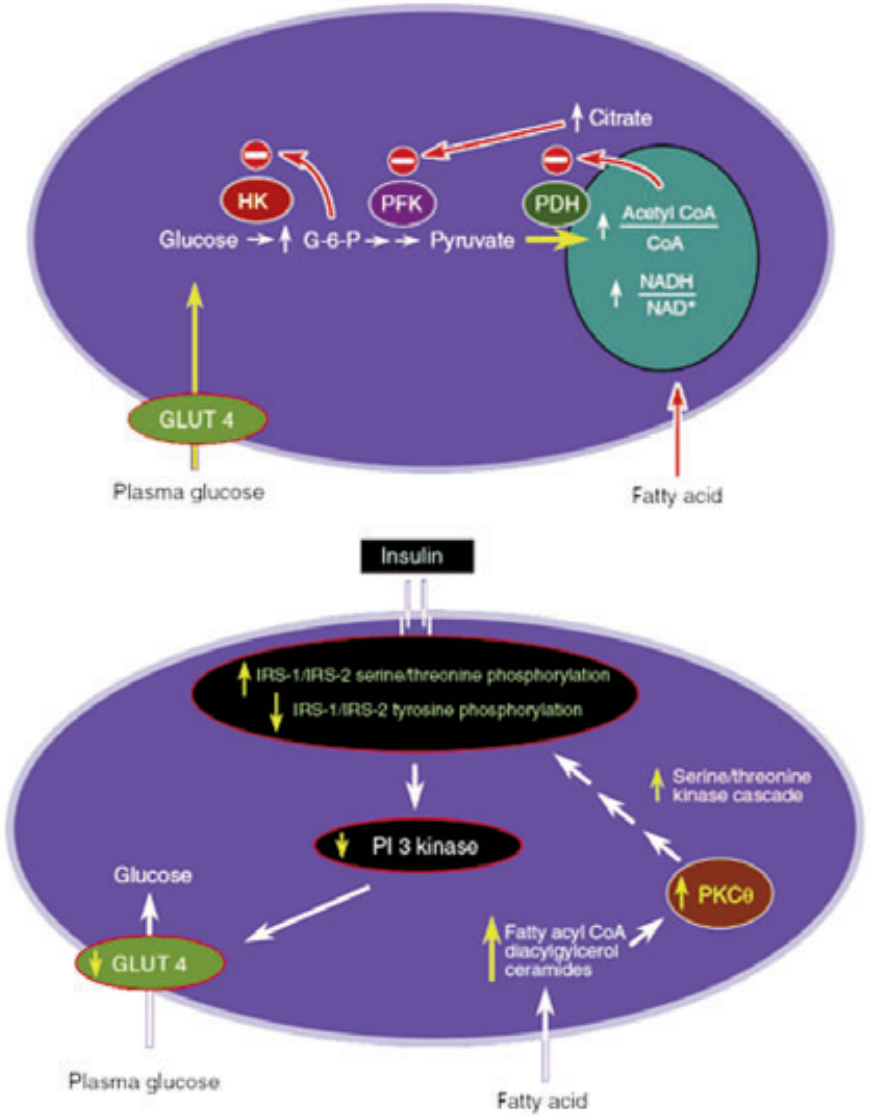

Figure 3: Top: Mechanism of fatty acid-induced insulin resistance in skeletal muscle as proposed by Randle et al. Bottom: Proposed alternative mechanism for fatty acid-induced insulin resistance in human skeletal muscle. From (Shulman, 2000). 
metabolites in muscle might be expected to induce insulin resistance. Evidence supporting this hypothesis comes from recent studies in mutant mice lipoatrophy. ${ }^{35,36}$ The study findings are consistent with the hypothesis that insulin resistance develops in obesity, type 2 diabetes, and lipodystrophy because of alterations in the partitioning of fat between the adipocyte and muscle tissue. This hypothesis might explain how thiazolidinediones improve insulin sensitivity in muscle as has been explored by Hevener and coworkers. ${ }^{37}$ By activating peroxisome proliferator-activated receptors in adipocytes and promoting adipocyte differentiation, these agents might promote a redistribution of fat from muscle into the adipocyte ${ }^{20}$ or perhaps act to alter lipid metabolism in muscle. ${ }^{38}$ It might also be expected that any alteration in the ability of muscle to metabolize fatty acids would also lead to increased intramyocellular lipid and subsequent defects in insulin signaling.

\section{The Role of Oxidative Stress in Accumulated Fat in the Development of Metabolic Syndrome in Obesity}

Oxidative stress has been defined as a disturbance of the cellular redox state resulting either from excess oxidative load or from inadequate nutrient supply favouring pro-oxidant reactions. Essentially there is an imbalance between antioxidant and prooxidant states. Increased oxidative stress results in the production of free radicals generated through reactive oxygen species (ROS; e.g. superoxide $\mathrm{O}_{2}{ }^{\bullet-}$, hydrogen peroxide $\mathrm{H}_{2} \mathrm{O}_{2}$, and hydroxyl radical $\bullet \mathrm{OH}$ ) and reactive nitrogen species (RONS; e.g. peroxynitrite $\mathrm{ONOO}^{-}$). Increased oxidative stress in accumulated fat causes dysregulation of adipokines which is an important pathogenic mechanism of obesity-related metabolic syndrome. ${ }^{39}$ Adipocytes produce a variety of biologically active molecules collectively known as adipokines, including plasminogen activator inhibitor-1 (PA1-1), ${ }^{40}$ tumour necrosis factor (TNF)-alpha, ${ }^{41}$ resistin, ${ }^{42}$ leptin,${ }^{43}$ adiponectin $^{44}$ and retinol binding protein-4 (RBP4). ${ }^{45}$ Adipokines are hormones that signal changes in fatty-tissue mass and energy status in order to control fuel usage. Adipokines can either enhance (e.g. leptin, adiponectin) or impair (e.g. fatty acids, TNF-alpha, resistin, RBP4) insulin action. ${ }^{46}$ Dysregulated production of adipokines may contribute to the pathogenesis of obesity-associated metabolic syndrome. Adiponectin exerts insulin-sensitizing effects $^{47}$ and hence low adiponectin levels, characteristic of obese states, which may contribute to insulin resistance. In diabetes, oxidative stress impairs glucose uptake in muscle and fat $^{48,49}$ and decreases insulin secretion from pancreatic $\beta$-cells. ${ }^{50}$ Furukawa and colleagues ${ }^{51}$ have shown that fat accumulation correlates with systemic oxidative stress in humans and mice. Production of reactive oxygen species was selectively increased in adipose tissue of obese mice and was accompanied by augmented expression of nicotinamide adenine dinucleotide phosphate oxidase and decreased expression of antioxidative enzymes. It was thus concluded that increased oxidative stress in accumulated fat is an early instigator of metabolic syndrome and that the redox state in adipose tissue is a potentially useful therapeutic target for obesity-associated metabolic syndrome (see Figure 4 and Steps 5-8 of Figure 2).

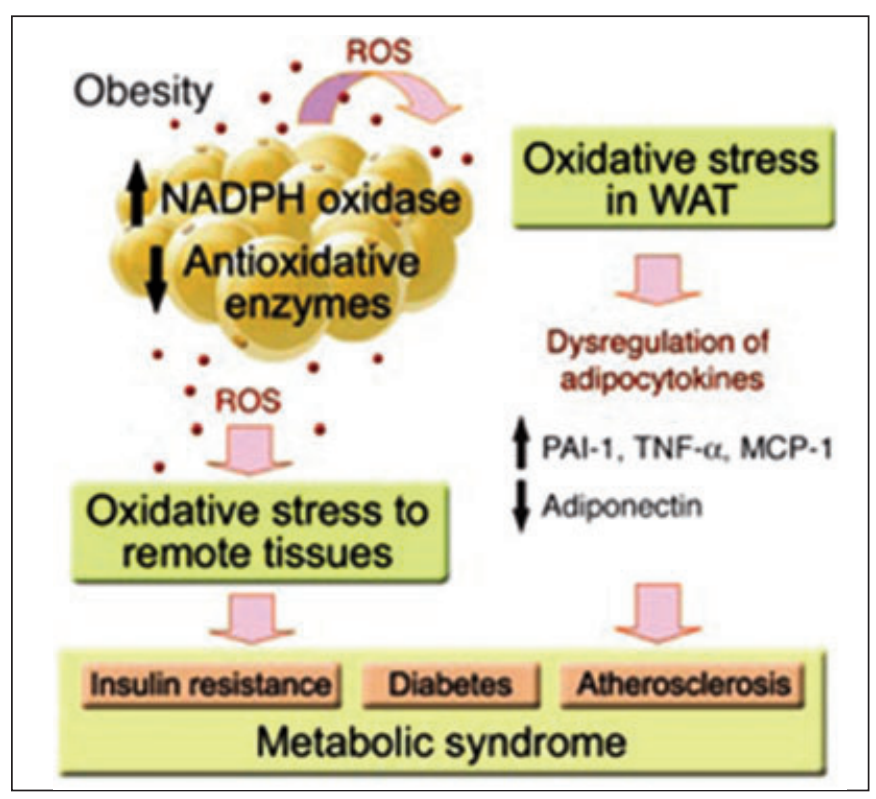

Figure 4: A working model illustrating how increased ROS production in accumulated fat contributes to metabolic syndrome. From (Furukawa et al, 2004).

The Role of Mitochondrial Dysfunction in the Development of Metabolic Syndrome in Obesity

The distribution of energy within myocytes is served by the adenosine triphosphate (ATP)-phosphocreatine shuttle and by subcellular compartment-alization of mitochondria. ${ }^{52}$ Subsarcolemmal mitochondria generate ATP for energyrequiring processes at the cell surface. ${ }^{53}$ Mitochondria may therefore be crucial for regulation of fatty acid oxidation and the propagation of insulin signaling, ${ }^{53}$ each of which is important to insulin action and thus potentially to the pathogenesis of insulin resistance in obesity and type 2 diabetes ${ }^{24,54,55}$ (see Step 9, Figure 2 ). Reduced oxidative enzyme capacity is correlated with the severity of the insulin resistance,${ }^{56}$ the reduced capacity for lipid oxidation $^{21}$ and an increased risk for obesity. ${ }^{57}$ In one study, subsarcolemmal mitochondrial electron transport chain activity was reduced 3.5-fold in obese subjects and 7-fold in type 2 diabetes. ${ }^{58}$ Other studies also suggest that mitochondrial dysfunction may be involved in the pathogenesis of metabolic syndrome. ${ }^{28,59,60}$

There are several possible mechanisms to explain the observed mitochondrial dysfunction that occurs in obesity. One attractive hypothesis is that a propensity towards lipid accumulation is caused by impaired fatty acid oxidation. ${ }^{20,21}$ IMCL accumulation and microvesicular steatosis liver are pathological hallmarks of fatty acid oxidation defects and are also frequently seen in mitochondrial respiratory chain defects. ${ }^{61}$ Gene array expression analyses have shown significant decreases in the nuclear expression of genes encoding proteins of oxidative phosphorylation and other mitochondrial proteins in type 2 diabetes. ${ }^{62,63}$ Non-invasive assessments of oxidative phos- 
phorylation of the soleus muscle using magnetic resonance spectroscopy have also indicated mitochondrial dysfunction in insulin resistance which appears to be associated with increased intramyocellular lipid. ${ }^{59,64}$ Reductions in oxidative enzymes have thus been implicated as a causative factor for impaired fatty acid oxidation in muscle during fasting in type 2 diabetes and obesity. ${ }^{15,21,60}$

\section{Potential Mechanism for Mitochondrial Dysfunction: Inhibition of Mitochondrial Adenine Nucleotide Transporters}

The adenine nucleotide transporter (ANT) catalyzes the exchange of adenosine di-phosphate (ADP) and adenosine triphosphate (ATP) across the inner mitochondrial membrane ${ }^{65}$ and is generally accepted as the overall rate-limiting step in oxidative phosphorylation and thus responsible for respiratory control. ${ }^{66}$ Long-chain acyl-CoA esters are potent inhibitors of this ANT in isolated mitochondria ${ }^{67,68}$ suggesting that they may act as important modulators of the transporter in vivo and hence control cellular energy metabolism (see Step 3 of Figure 2). Pande and Blanchaer ${ }^{68}$ have suggested that this inhibition serves to regulate the proportioning of long chain acyl-CoA esters between their utilization for oxidation and for triglyceride formation depending upon the availability of free fatty acids and existing cell energy needs. Thus, the accumulation of intra-myocellular lipids or fatty acids in the muscle may inhibit ANT leading to mitochondrial dysfunction in obesity. Mechanisms that could explain the effects of ANT1 (heart and skeletal muscle-specific isoform) dysfunction on mitochondrial DNA (mtDNA) stability include imbalance of the intra-mitochondrial deoxyribonucleotide triphosphate pool, caused by relative shortage of ATP supply needed for mtDNA synthesis, ${ }^{69}$ damage to mtDNA by overproduction of ROS, ${ }^{70}$ or instability of the mitochondrial permeability transition pore (of which it is a part) and apoptosis. ${ }^{71}$ Palmieri et $\mathrm{al}^{72}$ suggest that reduced matrix ADP, due to loss of ADP/ATP translocation, could inhibit ATP synthase, blocking proton influx into the matrix. The electrochemical gradient could then increase up to a level at which respiration-linked proton pumping and electron flow are both stalled leading to increased reactive oxygen species. ${ }^{73,74}$

\section{Potential Mechanism for Mitochondrial Dysfunction: Intramyocellular Lipid-Induced Oxidative Stress}

Increased intramyocellular lipid will increase cellular oxidative stress with subsequent production of reactive oxygen species, promoting lipid membrane peroxidative injury of mitochondrial membranes (see Steps 6-8 of Figure 2). This, in turn, may impair key membrane-associated oxidative enzymes such as Complex-I activity of the respiratory chain and longchain L-3-hydroxyacyl CoA dehydrogenase activity in fatty acid oxidation (see Step 5 of Figure 2). Mutant mitochondrial Complex I deficiency is associated with excessive ROS. ${ }^{75}$ The mitochondrial respiratory chain produces ROS as by-products of electron transport. ${ }^{76}$ These radicals are produced in the form of superoxide $\left(\mathrm{O} 2 \bullet^{-}\right)$or hydroxyl radicals $(\bullet \mathrm{OH})$. Highly reactive - $\mathrm{OH}$ readily reacts with a variety of molecules causing membrane lipid peroxidation protein aggregation and DNA hydroxylation. ${ }^{77}$ In long-chain fatty acid oxidation disorders, there is an accumulation of long-chain acyl-CoA's which may be relevant as this has also been observed in obesity, as previously established (see Step 3 of Figure 2). Excessive palmitoyl-CoA and palmitoylcarnitine have been shown to have detergent properties on isolated canine myocytic sarcolemmal membranes and to potentiate free radical induced lipid membrane peroxidative injury in ischemia. ${ }^{78}$

\section{Integration: Two Primary Potential Mechanisms for Muscle Metabolic Dysfunction in Obesity}

There are two events that may lead to intramyocellular lipid accumulation and mitochondrial dysfunction in patients with obesity. First, obesity with high intake-associated lipid accumulation in muscle interferes with cellular mitochondrial function through the generation of ROS leading to lipid membrane peroxidative injury and disruption of mitochondrial membrane-dependent enzymes thereby resulting in decreased oxidative metabolism. Secondly, a primary defect ${ }^{64}$ in mitochondrial oxidative metabolism may be responsible for a reduction in fatty acid oxidation leading to intramyocellular lipid accumulation as a secondary event. Alternatively, both processes may be present, given the likely multifactorial nature of environmental and genetic factors predisposing to obesity and the development of the metabolic syndrome.

\section{Potential Methods for Examining Muscle Lipids and Mitochondrial Oxidative Dysfunction}

In vivo magnetic resonance imaging (MRI), and magnetic resonance spectroscopy (MRS) are safe non-invasive techniques that are rapidly becoming popular approaches for assessing tissue metabolism. Unlike other in vivo methodologies there is no injection of radioactive materials (e.g. positron emission tomography) and no application of external ionizing radiation (as with computed tomography). Magnetic resonance spectroscopy techniques use non-ionizing radiowaves to probe tissue metabolic composition and metabolite molecular structure. As the approach is non-ionizing, patients/subjects can be scanned repeatedly with no risk of adverse effects. An additional advantage of MRS is the breadth of 'visible' atomic nuclei that may be probed. Most commonly the proton (i.e. ${ }^{1} \mathrm{H}$ ) is evaluated. However in vivo metabolic evaluation of tissue carbon $\left({ }^{13} \mathrm{C}\right)$, sodium $\left({ }^{23} \mathrm{Na}\right)$, and phosphorous $\left({ }^{31} \mathrm{P}\right)$ metabolism is also possible which allows for the measurement of many metabolites. MRS values for IMCL content are very well correlated to those obtained by direct visualization with electron microscopy. ${ }^{79}$ The advantage of the electron microscopy method is that it can provide a direct measurement of the size and distribution of both IMCL and mitochondria, ${ }^{80}$ which is important given that areas such as the sub-sarcolemmal region of the muscle appear to contain dysfunctional mitochondria that are better correlated with dysglycemia. ${ }^{58}$ Furthermore, electron miscroscopy can show the relationship between the mitochondria and the IMCL that may provide structural-functional relationships of importance in understanding exercise training adaptation and the metabolic syndrome ${ }^{80}$ (see Figure 1). The major downside of the electron microscopy method is that it requires a muscle biopsy and limits repeated measures assessment in certain populations.

The most common approach to studying in vivo metabolism is ${ }^{1} \mathrm{H}-\mathrm{MRS}$ : it can be done using any MRI system with a 
spectroscopy pulse sequence (manufacturer's software). This technique can be used to distinguish between and quantify extramyocellular lipid (EMCL) and intramyocellular lipid, ${ }^{47}$ by detecting proton resonances associated with methylene groups of fatty acids present in tissue triglycerides. Additional primary muscle metabolites that can be measured with ${ }^{1} \mathrm{H}-\mathrm{MRS}$ include creatine, choline, and taurine (see Figure 5) as well as dipeptide carnosine, homocarnosine, and adenosine. There has been considerable interest in muscle IMCL content due to observations that it is increased in insulin resistant subjects; for example the IMCL content of anterior tibialis and soleus were higher in subjects with lower glucose metabolic clearance ratio. ${ }^{81}$ In subjects with juvenile obesity a strong inverse correlation between soleus IMCL levels and insulin sensitivity was noted, which became even more convincing when percent total body fat and abdominal subcutaneous fat mass were controlled. ${ }^{82}$ This correlation has been confounded by the observation that IMCL

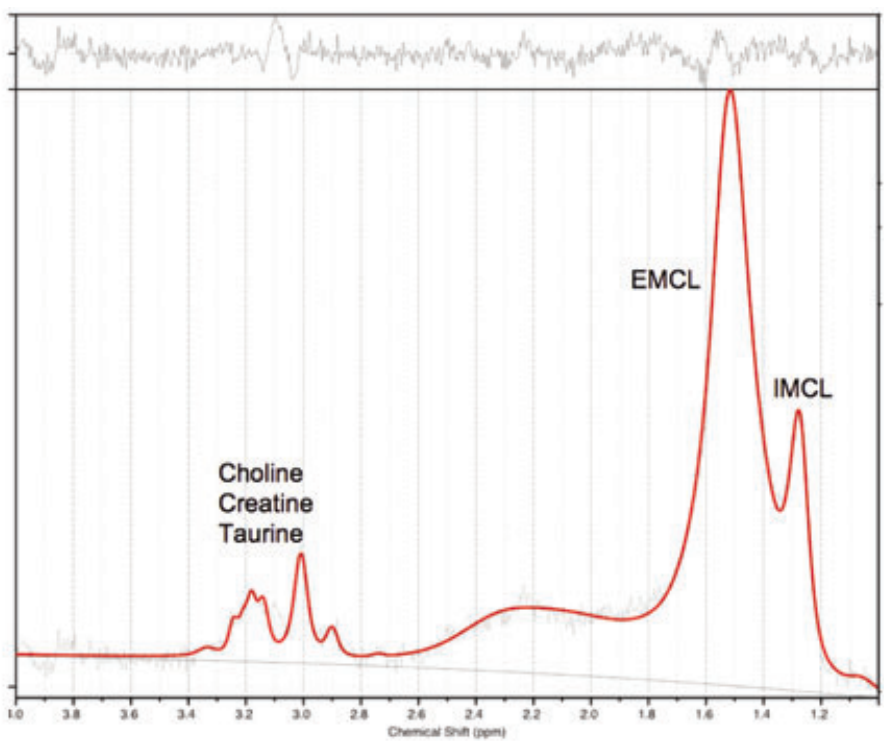

Figure 5: A typical ${ }^{1} H$-MRS spectrum with measured metabolites indicated. From M. Noseworthy, 2007 (unpublished results).

levels correlate with insulin sensitivity in endurance athletes, when compared to sedentary controls. ${ }^{83}$ Thus it appears that elevated IMCL levels predict insulin insensitivity only in untrained persons. In elite athletes this is reversed and high IMCL correlates to high insulin sensitivity (see Boesch et $\mathrm{al}^{84}$ for an excellent review of muscle ${ }^{1} \mathrm{H}-\mathrm{MRS}$ ). Exercise studies on EMCL and IMCL levels have proven useful for the evaluation of muscle lipid metabolism. ${ }^{84}$ Typically the IMCL ratio will be preferentially reduced following intense muscle activity, increasing back to pre-exercise conditions within 24 or 48 hours.
In elite athletes, recovery time can be considerably decreased to be within a few hours, which could be due to the fact that athletes have more mitochondria and mitochondrial enzyme activity and more IMCL is in contact with these mitochondria. ${ }^{80}$

Some research has been done to quantify fat content of muscle using fat selective magnetic resonance imaging methods combined with segmentation. ${ }^{48,49}$ For example standard magnetic resonance images provide visualization of fatty septa in muscle and in subcutaneous adipose tissue. The MR methods that do not utilize spectroscopic imaging cannot differentiate between the various lipid pools present in muscle, however they will provide rudimentary measure of tissue gross total fat content. More recently a spectroscopic imaging procedure with high spatial resolution has been developed that permits quantification of EMCL and IMCL levels with $0.7 \times 1.4 \mathrm{~mm}$ resolution. ${ }^{85}$ Thus, non-invasive techniques for accurate and direct measurement of lipid levels in muscle are currently available to researchers.

In addition to non-invasive measures of ${ }^{1} \mathrm{H}-\mathrm{MRS}$ researchers also have the ability to non-invasively evaluate phosphorous $\left({ }^{31} \mathrm{P}\right)$ metabolism. Exercise protocols combined with phosphorus magnetic resonance spectroscopy $\left({ }^{31} \mathrm{P}-\mathrm{MRS}\right)$ have become an

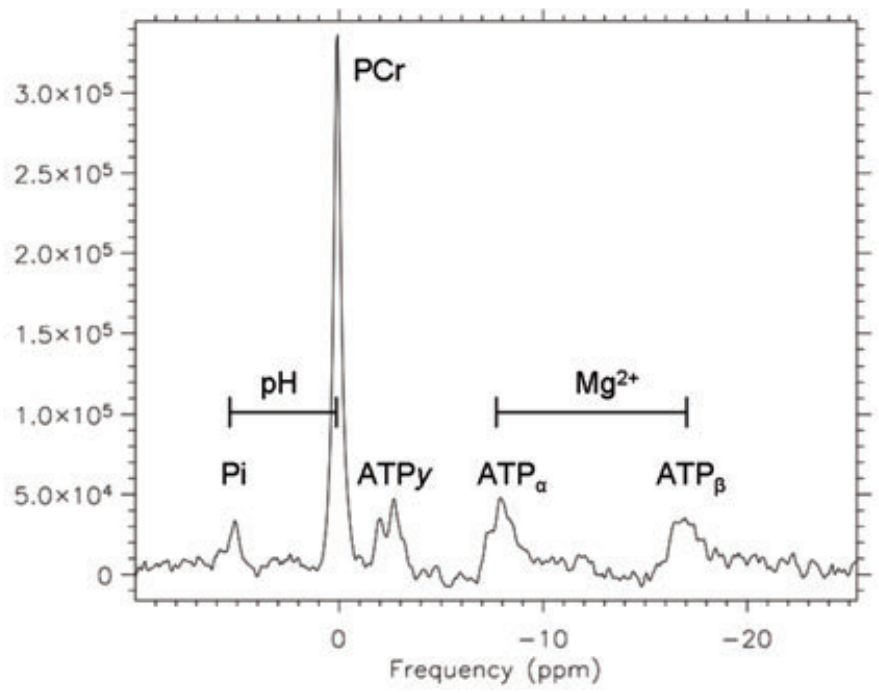

Figure 6: A typical ${ }^{31} P-M R S$ spectrum with measured metabolites indicated. From G. Wells, 2007 (unpublished results).

additional effective non-invasive technique to detect abnormalities in mitochondrial oxidative and glycolytic / glycogenolytic metabolism. The primary metabolites visible using this approach are ATP (3 distinctive peaks corresponding to $A, B$ and $Y$ phosphates), phosphocreatine ( $\mathrm{PCr}$ ), inorganic phosphate $(\mathrm{Pi})$, and phosphate mono and diesters. In addition, 

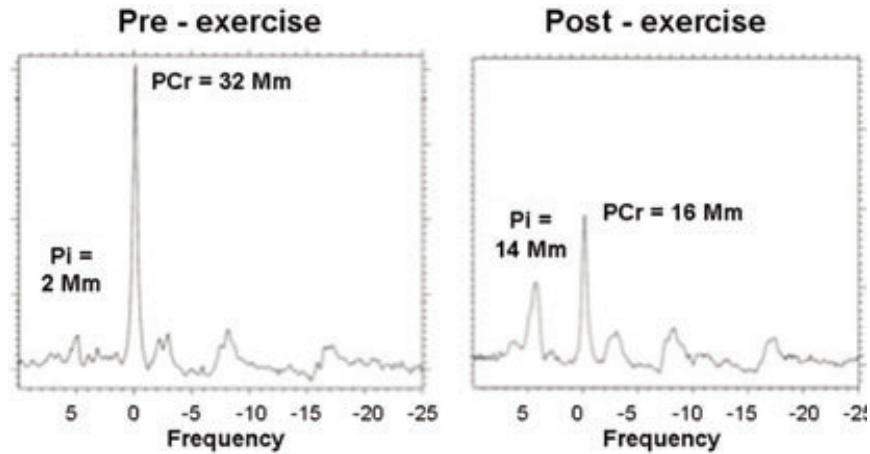

Figure 7: Typical ${ }^{31} P$-MRS spectra pre-and post-exercise. From G. Wells, 2007 (unpublished results).

intracellular $\mathrm{pH}$ and $\mathrm{Mg}^{2+}$ can be calculated based on the chemical shift of Pi and $B$-ATP, respectively (see Figure 6), and examination of the changes in the metabolites pre and post exercise (see Figure 7) can provide an indication of bio-energetic activity. For example, Prompers and colleagues ${ }^{86}$ have shown that the recovery rate of phosphocreatine after exercise is related to mitochondrial oxidative function. A combination of magnetic resonance imaging to assess body composition, ${ }^{1} \mathrm{H}-\mathrm{MRS}$ spectroscopy to assess intramuscular lipid accumulation, and ${ }^{31} \mathrm{P}$-MRS to assess muscle mitochondrial metabolism may become a potent tool for the non-invasive assessment of in vivo muscle function in patients with obesity.

\section{A Physiological Mechanism by which Exercise has a Positive Effect on Muscle Metabolism in Patients with Obesity and Metabolic Syndrome}

Exercise and physical activity may be powerful interventions for the treatment of obesity and metabolic syndrome ${ }^{87}$ with benefits that include improved body composition, ${ }^{88}$ cardiovascular function, ${ }^{89}$ nervous system function, ${ }^{90}$ energy balance and other positive effects. Exercise has specific positive impact on obesity and metabolic syndrome via induced changes in the muscle as well, likely through activation of the enzyme AMP kinase.

Exercise activates AMP kinase, which stimulates fatty acid oxidation, glucose uptake and mitochondrial biogenesis and is a critical metabolite-sensing protein that acts as a fuel gauge to monitor cellular energy. ${ }^{91}$ When AMP kinase "senses" decreased energy storage, it acts to switch off ATP-consuming pathways and switch on pathways for ATP regeneration. AMP kinase is rapidly activated in tissues and cells in the presence of ischemia, hypoxia, inhibition of glycolysis, and uncouplers of oxidative phosphorylation ${ }^{91}$ and interleukin- $6 .{ }^{92}$ Contractile activity alters the fuel status of muscle and depending upon intensity of contractions there can be major decreases in both phosphocreatine and ATP, resulting in an increase in the AMP-to-ATP and creatine-to-phosphocreatine ratio which also served to activate
AMP kinase. Moderate-intensity cycle exercise (Fujii ${ }^{93}$ et al, 2000) and high intensity "sprint" exercise have been shown to increase muscle AMP kinase. ${ }^{94}$

Activation of AMP kinase through exercise and physical activity may be beneficial for patients with obesity and metabolic syndrome as this enzyme plays a role in contractionstimulated glucose uptake, ${ }^{95,96}$ even when there is impaired insulin signaling in skeletal muscle in type 2 diabetes.97 Increased AMP kinase activity also improves fatty acid oxidation regulation in as little as one exercise session. ${ }^{98}$ This occurs through AMP kinase phosphorylation of the $\beta$-isoform of acetylCoA carboxylase (ACC), resulting in ACC inactivation, a fall in malonyl-CoA content (inhibitor of carnitine palmityoyltransferase I, the rate limiting enzyme of long-chain fatty acid oxidation), and subsequent increases in fatty acid oxidation ${ }^{99,100}$ (see Figure 8). Increased AMP kinase activity is also associated with increased cytochrome-c content, mitochondrial density, and DNA binding activity of nuclear respiratory factor-1, a transcription factor that acts on a nuclear set of genes required for transcription of respiratory chain proteins in addition to mitochondrial transcription and replication. ${ }^{101}$ The positive effects of AMP kinase on muscle glucose metabolism, fatty acid regulation, and mitochondrial function provide a physiological

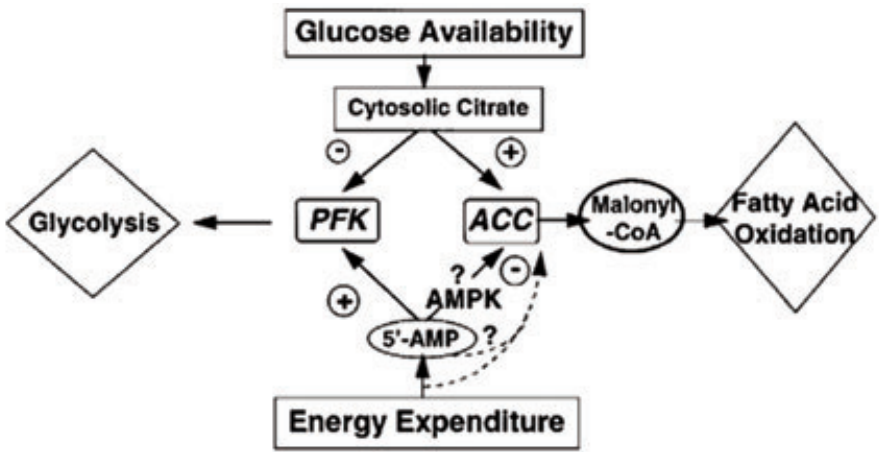

Figure 8: Proposed dual mechanism of regulation of glycolysis and fatty acid oxidation. It is hypothesized that increased glucose availability acutely activates ACC- $\beta$ and inhibits PFK by increasing cytosolic levels of citrate, whereas increased energy expenditure (exercise) activates $P F K$ and inhibits ACC- $\beta$ by increasing the concentration of free $5^{1}-A M P$. The effect of $5^{1}-A M P$ on ACC- $\beta$ is attributed to activation of $5^{1}-A M P$ activated kinase. According to the proposed scheme, fatty acid oxidation will be restrained or enhanced, at least in part, by the resultant change in the concentration of malonyl-CoA and glycolysis by the change in the activity of PFK. During intense contraction, when both cytosolic citrate and $5^{1}$-AMP are increased, the $5^{I}$-AMP-mediated effects appear to take precedence in regulating fatty acid oxidation. From (Vavvas et al., 1997).

justification for the use of exercise in the treatment of metabolic syndrome and obesity, and also may be variables of interest in training studies in these patients, although gender differences may need to be considered. ${ }^{102}$ 


\section{SUMMARY}

The impact of obesity and metabolic syndrome on the metabolism of muscle has been presented in detail, and two primary physiologic mechanisms to explain the observed metabolic dysfunction have been proposed. Further, noninvasive magnetic resonance techniques (MRI/MRS) for the assessment of muscle metabolic dysfunction have been suggested. These techniques have the potential to be used noninvasively to assess the impact of new treatment modalities. The potential of exercise programming for the treatment of obesity and metabolic syndrome is great, and a physiologic rationale for this treatment modality has been outlined.

\section{REFERENCES}

1. Vanasse A, Demers M, Hemiari A, Courteau J. Obesity in Canada: where and how many? Int J Obes. 2005;30(4):677-83.

2. Dietitians of Canada, Canadian Paediatric Society, College of Family Physicians of Canada, Community Health Nurses Association of Canada. The use of growth charts for assessing and monitoring growth in Canadian infants and children. Can J Diet Pract Res. 2004;65(1):22-32.

3. Tremblay MS, Willms JD. Secular trends in the body mass index of Canadian children. CMAJ. 2000;163(11):1429-13.

4. Sheilds M. Overweight and obesity among children and youth. Health Rep. 2006 Aug; 17(3):27-42.

5. Caprio S, Genel M. Confronting the epidemic of childhood obesity. Pediatrics. 2005;115(2):494-5.

6. Kaur H, Hyder ML, Poston WS. Childhood overweight: An expanding problem. Treat Endocrinol. 2003;2(6):375-88.

7. Strock GA, Cottrell ER, Abang AE, Buschbacher RM, Hannon TS. Childhood obesity: A simple equation with complex variables. J Long Term Eff Med Implants 2005;15(1):15-32.

8. Clement K, Ferre P. Genetics and the pathophysiology of obesity. Pediatr Res. 2003;53(5):721-5.

9. Weiss R, Dziura J, Burgert TS, Tamborlane WV, Taksali SE, Yeckel $\mathrm{CW}$, et al. Obesity and the metabolic syndrome in children and adolescents. N Engl J Med. 2004;350(23):2362-74.

10. Sinha R, Fisch G, Teague B, Tamborlane WV, Banyas B, Allen K, et al. Prevalence of impaired glucose tolerance among children and adolescents with marked obesity. $\mathrm{N}$ Engl J Med. 2002;346(11):802-10.

11. Speiser PW, Rudolf MC, Anhalt H, Camacho-Hubner C, Chiarelli F, Eliakim A, et al. Childhood obesity. J Clin Endocrinol Metab. 2005;90(3):1871-87.

12. Bjorntorp P. Abdominal obesity and the metabolic syndrome. Ann Med. 1992;24(6):465-8.

13. Weiss R, Dufour S, Taksali SE, Tamborlane WV, Petersen KF, Bonadonna RC, et al. Prediabetes in obese youth: a syndrome of impaired glucose tolerance, severe insulin resistance, and altered myocellular and abdominal fat partitioning. Lancet. 2003;362(9388):951-7.

14. Bonen A, Dohm GL, van Loon LJ. Lipid metabolism, exercise and insulin action. Essays Biochem. 2006;42:47-59.

15. Kelley DE, Goodpaster B, Wing RR, Simoneau JA. Skeletal muscle fatty acid metabolism in association with insulin resistance, obesity, and weight loss. Am J Physiol. 1999;277(6 Pt 1):E1130-41.

16. Pan DA, Lillioja S, Kriketos AD, Milner MR, Baur LA, Bogardus $\mathrm{C}$, et al. Skeletal muscle triglyceride levels are inversely related to insulin action. Diabetes. 1997;46(6):983-8.

17. Malenfant P, Joanisse DR, Theriault R, Goodpaster BH, Kelley DE, Simoneau JA. Fat content in individual muscle fibers of lean and obese subjects. Int J Obes Relat Metab Disord. 2001;25(9): 1316-21.

18. McGarry JD. Banting lecture 2001: dysregulation of fatty acid metabolism in the etiology of type 2 diabetes. Diabetes. 2002;51(1):7-18.
19. Simoneau JA, Colberg SR, Thaete FL, Kelley DE. Skeletal muscle glycolytic and oxidative enzyme capacities are determinants of insulin sensitivity and muscle composition in obese women. FASEB J. 1995;9(2):273-8.

20. Kim JY, Hickner RC, Cortright RL, Dohm GL, Houmard JA. Lipid oxidation is reduced in obese human skeletal muscle. Am J Physiol Endocrinol Metab. 2000;279(5):E1039-44.

21. Simoneau JA, Veerkamp JH, Turcotte LP, Kelley, DE. Markers of capacity to utilize fatty acids in human skeletal muscle: relation to insulin resistance and obesity and effects of weight loss. FASEB J. 1999;13(14):2051-60.

22. Ravikumar B, Carey PE, Snaar JE, Deelchand DK, Cook DB, Neely RD, et al. Real-time assessment of postprandial fat storage in liver and skeletal muscle in health and type 2 diabetes. Am J Physiol Endocrinol Metab. 2005;288(4):E789-97.

23. Goodpaster BH, Kelley DE. Skeletal muscle triglyceride: marker or mediator of obesity-induced insulin resistance in type 2 diabetes mellitus? Curr Diab Rep. 2002;2(3):216-22.

24. Shulman GI. Cellular mechanisms of insulin resistance. J Clin Invest. 2000;106(2):171-6.

25. Bonadonna RC, Del Prato S, Bonora E, Saccomani MP, Gulli G, Natali A, et al. Roles of glucose transport and glucose phosphorylation in muscle insulin resistance of NIDDM. Diabetes. 1996;45(7):915-25.

26. Kelley DE, Mintun MA, Watkins SC, Simoneau JA, Jadali F, Fredrickson A, et al. The effect of non-insulin-dependent diabetes mellitus and obesity on glucose transport and phosphorylation in skeletal muscle. J Clin Invest. 1996;97(12):2705-13.

27. Saltiel AR, Kahn CR. Insulin signalling and the regulation of glucose and lipid metabolism. Nature. 2001;414(6865):799-806.

28. Kelley DE, He J, Menshikova EV, Ritov VB. Dysfunction of mitochondria in human skeletal muscle in type 2 diabetes. Diabetes. 2002;51(10):2944-50.

29. Brechtel K, Dahl DB, Machann J, Bachmann OP, Wenzel I, Maier $\mathrm{T}$, et al. Fast elevation of the intramyocellular lipid content in the presence of circulating free fatty acids and hyperinsulinemia: a dynamic 1H-MRS study. Magn Reson Med. 2001;45(2):179-83.

30. Boden G, Chen X, Rosner J, Barton M. Effects of a 48-h fat infusion on insulin secretion and glucose utilization. Diabetes. 1995;44(10):1239-42.

31. Roden M, Price TB, Perseghin G, Petersen KF, Rothman DL, Cline $\mathrm{GW}$, et al. Mechanism of free fatty acid-induced insulin resistance in humans. J Clin Invest. 1996;97(12):2859-65.

32. Man ZW, Hirashima T, Mori S, Kawano K. Decrease in triglyceride accumulation in tissues by restricted diet and improvement of diabetes in otsuka long-evans tokushima fatty rats, a non-insulindependent diabetes model. Metabolism. 2000;49(1):108-14.

33. Ohneda M, Inman LR, Unger RH. Caloric restriction in obese prediabetic rats prevents beta-cell depletion, loss of beta-cell GLUT 2 and glucose incompetence. Diabetologia. 1995;38(2):173-9.

34. Goodpaster BH, Wolf D. Skeletal muscle lipid accumulation in obesity, insulin resistance, and type 2 diabetes. Pediatr Diabetes. 2004:5(4):219-26.

35. Gavrilova O, Marcus-Samuels B, Graham D, Kim JK, Shulman GI, Castle AL, et al. Surgical implantation of adipose tissue reverses diabetes in lipoatrophic mice. J Clin Invest. 2000; 105(3):271-8.

36. Kim JK, Gavrilova O, Chen Y, Reitman ML, Shulman GI. Mechanism of insulin resistance in A-ZIP/F-1 fatless mice. J Biol Chem. 2000a;275(12):8456-60.

37. Hevener AL, He W, Barak Y, Le J, Bandyopadhyay G, Olson P, et al. Muscle-specific Pparg deletion causes insulin resistance. Nature Med. 2003;9(12):1491-7.

38. Norris AW, Chen L, Fisher SJ, Szanto I, Ristow M, Jozsi AC, et al. Muscle-specific PPARgamma-deficient mice develop increased adiposity and insulin resistance but respond to thiazolidinediones. J Clin Invest. 2003;112(4):608-18.

39. Palming J, Sjöholm K, Jernås M, Lystig TC, Gummesson A, Romeo $\mathrm{S}$, et al. The expression of $\mathrm{NAD}(\mathrm{P}) \mathrm{H}$ :quinone oxidoreductase 1 is high in human adipose tissue, reduced by weight loss, and correlates with adiposity, insulin sensitivity, and markers of liver dysfunction. J Clin Endocrinol Metab. 2007; 92(6):2346-52. 
40. Shimomura I, Funahashi T, Takahashi M, Maeda K, Kotani K, Nakamura T, et al. Enhanced expression of PAI-1 in visceral fat: possible contributor to vascular disease in obesity. Nature Med. 1996;2(7):800-3.

41. Hotamisligil GS, Shargill NS, Spiegelman BM. Adipose expression of tumor necrosis factor-alpha: direct role in obesitylinked insulin resistance. Science. 1993;259(5091):87-91.

42. Steppan CM, Bailey ST, Bhat S, Brown EJ, Banerjee R, Wright $\mathrm{CM}$, et al. The hormone resistin links obesity to diabetes. Nature. 2001;409(6818):307-12

43. Friedman JM, Halaas JL. Leptin and the regulation of body weight in mammals. Nature. 1998;395(6704):763-70.

44. Berg AH, Combs TP, Scherer PE. ACRP30/adiponectin: an adipokine regulating glucose and lipid metabolism. Trends Endocrinol Metab. 2002;13(2):84-9

45. Yang Q, Graham TE, Mody N, Preitner F, Peroni OD, Zabolotny $\mathrm{JM}$, et al. Serum retinol binding protein 4 contributes to insulin resistance in obesity and type 2 diabetes. Nature. 2005; 436(7049):356-62.

46. Kershaw EE, Flier JS. Adipose tissue as an endocrine organ. J Clin Endocrinol Metab. 2004;89(6):2548-56

47. Yamauchi T, Kamon J, Waki H, Terauchi Y, Kubota N, Hara K, et al. The fat-derived hormone adiponectin reverses insulin resistance associated with both lipoatrophy and obesity. Nature Med. 2001;7(8):941-6.

48. Rudich A, Tirosh A, Potashnik R, Hemi R, Kanety H, Bashan N. Prolonged oxidative stress impairs insulin-induced GLUT4 translocation in 3T3-L1 adipocytes. Diabetes. 1998;47(10): $1562-9$

49. Maddux BA, See W, Lawrence JC Jr, Goldfine AL, Goldfine ID, Evans JL. Protection against oxidative stress-induced insulin resistance in rat L6 muscle cells by mircomolar concentrations of alpha-lipoic acid. Diabetes. 2001;50(2):404-10.

50. Matsuoka T, Kajimoto Y, Watada H, Kaneto H, Kishimoto M, Umayahara Y, et al. Glycation-dependent, reactive oxygen species-mediated suppression of the insulin gene promoter activity in HIT cells. J Clin Invest. 1997;99(1), 144-50.

51. Furukawa S, Fujita T, Shimabukuro M, Iwaki M, Yamada Y, Nakajima Y, et al. Increased oxidative stress in obesity and its impact on metabolic syndrome. J Clin Invest. 2004; 114(12):1752-61

52. Kaasik A, Veksler V, Boehm E, Novotova M, Minajeva A, VenturaClapier R. Energetic crosstalk between organelles: Architectural integration of energy production and utilization. Circ Res. 2001;89(2):153-9.

53. Hood DA. Invited review: contractile activity-induced mitochondrial biogenesis in skeletal muscle. J Appl Physiol. 2001;90(3):1137-57.

54. Saltiel AR. Series introduction: The molecular and physiological basis of insulin resistance: emerging implications for metabolic and cardiovascular diseases. J Clin Invest. 2000;106(2):163-4.

55. Shepherd PR, Kahn BB. Glucose transporters and insulin action-implications for insulin resistance and diabetes mellitus. N Engl J Med. 1999:341(4):248-57.

56. Colberg SR, Simoneau JA, Thaete FL, Kelley DE. Skeletal muscle utilization of free fatty acids in women with visceral obesity. J Clin Invest. 1995;95(4):1846-53.

57. Sun G, Ukkola O, Rankinen T, Joanisse DR, Bouchard C. Skeletal muscle characteristics predict body fat gain in response to overfeeding in never-obese young men. Metabolism. 2002; 51(4):451-6.

58. Ritov VB, Menshikova EV, He J, Ferrell RE, Goodpaster BH, Kelley DE. Deficiency of subsarcolemmal mitochondria in obesity and type 2 diabetes. Diabetes. 2005;54(1):8-14.

59. Petersen KF, Befroy D, Dufour S, Dziura J, Ariyan C, Rothman DL, et al. Mitochondrial dysfunction in the elderly: possible role in insulin resistance. Science. 2003;300(5622):1140-2.

60. Stump CS, Short KR, Bigelow ML, Schimke JM, Nair KS. Effect of insulin on human skeletal muscle mitochondrial ATP production, protein synthesis, and mRNA transcripts. Proc Natl Acad Sci USA. 2003;100(13):7996-8001.
61. Tein I. Metabolic myopathies. In: Swaiman KF, Ashwal S, Ferriero D, editors. Pediatric Neurology. 4th ed. Mosby-Yearbook Inc; 2006 p. 2023-73.

62. Mootha VK, Lindgren CM, Eriksson KF, Subramanian A, Sihag S, Lehar J, et al. PGC-1alpha-responsive genes involved in oxidative phosphorylation are coordinately downregulated in human diabetes. Nat Genet. 2003;34(3):267-73.

63. Patti ME, Butte AJ, Crunkhorn S, Cusi K, Berria R, Kashyap S, et al. Coordinated reduction of genes of oxidative metabolism in humans with insulin resistance and diabetes: potential role of PGC1 and NRF1. Proc Natl Acad Sci USA. 2003;100(14): 8466-71.

64. Petersen KF, Dufour S, Befroy D, Garcia R, Shulman GI. Impaired mitochondrial activity in the insulin-resistant offspring of patients with type 2 diabetes. N Engl J Med. 2004;350(7): 664-71.

65. Vignais PV. Molecular and physiological aspects of adenine nucleotide transport in mitochondria. Biochim Biophys Acta. 1976;456(1):1-38.

66. Lemasters JJ, Sowers AE. Phosphate dependence and atractyloside inhibition of mitochondrial oxidative phosphorylation. The ADP-ATP carrier is rate-limiting. J Biol Chem. 1979;254(4):1248-51.

67. Shug A, Lerner E, Elson C, Shrago E. The inhibition of adenine nucleotide translocase activity by oleoyl CoA and its reversal in rat liver mitochondria. Biochem Biophys Res Commun. 1971;43(3):557-63.

68. Pande SV, Blanchaer MC. Reversible inhibition of mitochondrial adenosine diphosphate phosphorylation by long chain acyl coenzyme A esters. J Biol Chem. 1971;246(2):402-11.

69. Kaukonen J, Juselius JK, Tiranti V, Kyttala A, Zeviani M, Comi $\mathrm{GP}$, et al. Role of adenine nucleotide translocator 1 in mtDNA maintenance. Science. 2000;289(5480):782-5.

70. Esposito LA, Melov S, Panov A, Cottrell BA, Wallace DC. Mitochondrial disease in mouse results in increased oxidative stress. Proc Natl Acad Sci USA. 1999;96(9):4820-5.

71. Marzo I, Brenner C, Kroemer G. The central role of the mitochondrial megachannel in apoptosis: evidence obtained with intact cells, isolated mitochondria, and purified protein complexes. Biomed Pharmacother. 1998;52(6):248-51.

72. Palmieri L, Alberio S, Pisano I, Lodi T, Meznaric-Petrusa M, Zidar $\mathrm{J}$, et al. Complete loss-of-function of the heart/muscle-specific adenine nucleotide translocator is associated with mitochondrial myopathy and cardiomyopathy. Hum Mol Genet. 2005; 14(20):3079-88.

73. McKenzie M, Liolitsa D, Hanna MG. Mitochondrial disease: mutations and mechanisms. Neurochem Res. 2004;29(3): 589-600.

74. Doudican NA, Song B, Shadel GS, Doetsch PW. Oxidative DNA damage causes mitochondrial genomic instability in Saccharomyces cerevisiae. Mol Cell Biol. 2005;25(12): 5196-204.

75. Pitkanen S, Robinson BH. Mitochondrial complex I deficiency leads to increased production of superoxide radicals and induction of superoxide dismutase. J Clin Invest. 1996; 98(2):345-51.

76. Boveris A, Oshino N, Chance B. The cellular production of hydrogen peroxide. Biochem J. 1972;128(3):617-30.

77. Cheeseman KH, Slater TF. An introduction to free radical biochemistry. Br Med Bull. 1993;49(3):481-93.

78. Mak IT, Kramer JH, Weglicki WB. Potentiation of free radicalinduced lipid peroxidative injury to sarcolemmal membranes by lipid amphiphiles. J Biol Chem. 1986;261(3):1153-7.

79. Howald H, Boesch C, Kreis R, Matter S, Billeter R, EssenGustavsson B, et al. Content of intramyocellular lipids derived by electron microscopy, biochemical assays, and (1)H-MR spectroscopy. J Appl Physiol. 2002;92(6):2264-72.

80. Tarnopolsky MA, Rennie CD, Robertshaw HA, FedakTarnopolsky SN, Devries MC, Hamadeh MJ. Influence of endurance exercise training and sex on intramyocellular lipid and mitochondrial ultrastructure, substrate use, and mitochondrial enzyme activity. Am J Physiol Regul Integr Comp Physiol. 2007;292(3):R1271-8. 
81. Jacob S, Machann J, Rett K, Brechtel K, Volk A, Renn W, et al. Association of increased intramyocellular lipid content with insulin resistance in lean nondiabetic offspring of type 2 diabetic subjects. Diabetes. 1999;48(5):1113-9.

82. Sinha R, Dufour S, Petersen KF, LeBon V, Enoksson S, et al. Assessment of skeletal muscle triglyceride content by $1 \mathrm{H}$ nuclear magnetic resonance spectroscopy in lean and obese adolescents. Diabetes. 2002;51:1022-7.

83. Decombaz J, Schmitt B, Ith M, Decarli B, Diem P, Kreis R, et al. Postexercise fat intake repletes intramyocellular lipids but no faster in trained than in sedentary subjects. Am J Physiol Regul Integr Comp Physiol. 2001;281(3):R760-9.

84. Boesch C, Machann J, Vermathen P, Schick F. Role of proton MR for the study of muscle lipid metabolism. NMR Biomed. 2006;19:968-88.

85. Weis J, Johansson L, Courivaud F, Karlsson FA, Ahlstrom H. Quantification of intramyocellular lipids in obese subjects using spectroscopic imaging with high spatial resolution. MAGMA. 2007;57:22-8.

86. Prompers JJ, Jeneson JA, Drost MR, Oomens CC, Strijkers GJ, Nicolay K. Dynamic MRS and MRI of skeletal muscle function and biomechanics. NMR Biomed. 2006;19(7):927-53.

87. Bianchi C, Penno G, Romero F, Del Prato S, Miccoli R. Treating the metabolic syndrome. Expert Rev Cardiovasc Ther. 2007;5(3):491-506.

88. Ildiko V, Zsofia M, Janos M, Andreas P, Dora NE, Andras P, et al. Activity-related changes of body fat and motor performance in obese seven-year-old boys. J Physiol Anthropol. 2007;26(3): 333-7.

89. Meyer AA, Kundt G, Lenschow U, Schuff-Werner P, Kienast W. Improvement of early vascular changes and cardiovascular risk factors in obese children after a six-month exercise program. J Am Coll Cardiol. 2006;48(9):1865-70.

90. Dishman RK, Berthoud HR, Booth FW, Cotman CW, Edgerton VR, Fleshner MR, et al. Neurobiology of exercise. Obesity (Silver Spring). 2006;14(3):345-56.

91. Hardie DG. AMP-activated protein kinase: a key system mediating metabolic responses to exercise. Med Sci Sports Exerc. 2004;36(1):28-34.

92. Ruderman NB, Keller C, Richard AM, Saha AK, Luo Z, Xiang X, et al. Interleukin-6 regulation of AMP-activated protein kinase. Potential role in the systemic response to exercise and prevention of the metabolic syndrome. Diabetes. 2006;55 S2:S48-54.
93. Fujii N, Hayashi T, Hirshman MF, Smith JT, Habinowski SA, Kaijser L, et al. Exercise induces isoform-specific increase in 5'AMP-activated protein kinase activity in human skeletal muscle. Biochem Biophys Res Commun. 2000;273(3):1150-5.

94. Chen ZP, McConell GK, Michell BJ, Snow RJ, Canny BJ, Kemp BE. AMPK signaling in contracting human skeletal muscle: Acetyl-CoA carboxylase and NO synthase phosphorylation. Am J Physiol Endocrinol Metab. 2000;279(5):E1202-6.

95. Hayashi T, Hirshman MF, Kurth EJ, Winder WW, Goodyear LJ. Evidence for 5' AMP-activated protein kinase mediation of the effect of muscle contraction on glucose transport. Diabetes. 1998;47(8): 1369-73.

96. Bergeron R, Russell RR3rd, Young LH, Ren JM, Marcucci M, Lee A, et al. Effect of AMPK activation on muscle glucose metabolism in conscious rats. Am J Physiol. 1999;276(5 Pt 1):E938-44.

97. Musi N, Fujii N, Hirshman MF, Ekberg I, Froberg S, Ljungqvist O, et al. AMP-activated protein kinase (AMPK) is activated in muscle of subjects with type 2 diabetes during exercise. Diabetes. 2001;50(5):921-7.

98. Schenk S, Horowitz JF. Acute exercise increases triglyceride synthesis in skeletal muscle and prevents fatty acid-induced insulin resistance. J Clin Invest. 2007;117(6):1690-8.

99. Hutber CA, Hardie DG, Winder WW. Electrical stimulation inactivates muscle acetyl-CoA carboxylase and increases AMPactivated protein kinase. Am J Physiol. 1997;272(2 Pt 1): E262-6.

100. Vavvas D, Apazidis A, Saha AK, Gamble J, Patel A, Kemp BE, et al. Contraction-induced changes in acetyl-CoA carboxylase and 5'-AMP-activated kinase in skeletal muscle. J Biol Chem. 1997;272(20):13255-61.

101. Bergeron R, Ren JM, Cadman KS, Moore IK, Perret P, Pypaert M, et al. Chronic activation of AMP kinase results in NRF-1 activation and mitochondrial biogenesis. Am J Physiol Endocrinol Metab. 2001;281(6):E1340-6

102. Tarnopolsky MA. Exercising women throw a wrench in the gears of the AMPK-lipid oxidation link. J Physiol. 2006 Jul 1;574 (Pt 1):1. 